\title{
How Can Sustainable Agriculture Increase Climate Resilience? A Systematic Review
}

\author{
Daniel El Chami ${ }^{1} \mathbb{D}$, André Daccache ${ }^{2}$ and Maroun El Moujabber ${ }^{3, *}$ \\ 1 Timac Agro Italia S.p.A., S.P.13-Località Ca' Nova, I-26010 Ripalta Arpina (CR), Italy; delchami@roullier.com \\ 2 Department of Biological and Agricultural Engineering, University of California, Davis (UC Davis), \\ CA 95616-5294, USA; adaccache@ucdavis.edu \\ 3 International Centre for Advanced Mediterranean Agronomic Studies (CIHEAM-IAM.B), Via Ceglie 9, \\ 70010 Valenzano (BA) , Italy \\ * Correspondence: elmoujabber@iamb.it; Fax: +39-080-4606-206
}

Received: 24 February 2020; Accepted: 10 April 2020; Published: 13 April 2020

check for updates

\begin{abstract}
In the last few decades, a great deal has been written on the use of sustainable agriculture to improve the resilience of ecosystem services to climate change. However, no tangible and systematic evidence exists on how this agriculture would participate in alleviating impacts on vulnerable rural communities. This paper provides a narrative systematic review (SR) integrated with a bibliometric analysis and a concept network analysis to determine how, in this changing climate, sustainable agriculture can increase the resilience of agrosystems. Our search ranged from the date of the first relevant article until the end of 2018. The results generated demonstrated the following: (a) Only single practices and methods have been studied to assess the impacts on single ecosystem services; (b) Soil quality and health are considered a key indicator of sustainable agriculture; (c) Although the assessed practices and methods were shown to improve the biodiversity of agrosystems, which makes them more resilient to extreme climate events, we are still far from developing interdisciplinary and multidimensional agriculture that integrates all management aspects and generates a full range of ecosystem services. In conclusion, this study addressed the following recommendations for the scientific community and policymakers to orient future research strategies and efforts: (a) The integration of all agrosystem services into sustainable management using an ecosystem-based approach on a life-cycle basis using the Life Cycle Assessment (LCA) method; (b) Improving the scientific understanding of traditional knowledge to facilitate greater synergy and further integration; (c) The unification of assessment methods and indicators for the quantification of impacts; (d) The creation of a platform to share, monitor, screen, and approve assessments and evaluations of sustainable agriculture by region.
\end{abstract}

Keywords: systematic review; sustainable agriculture; climate change; resilience; agrosystems

\section{Introduction}

Human-induced climate change, as defined by the WMO [1], was suspected in the early 19th century, but the scientific community did not form a strong and unified opinion about it until the second half of the century when a global consensus began to take a form [2].

Climate change is already having significant global impacts on weather, especially on the frequency, the intensity, the duration, and the spatial extent of extreme events [3]. While these changes are expected to produce some possible benefits (not well documented) to certain local areas, especially in terms of water availability and agriculture $[2,4,5]$, many scientists argue that their costs may counteract these benefits, endangering various aspects of life on Earth (i.e., social, ecological, and physical systems) [6,7]. Consequently, the sustainability of life on Earth is jeopardized by a) the worsening of the economic 
dimension and increased poverty, b) a compromised social dimension due to food insecurity, migration, and human health risks, and c) the deteriorating natural environment and ecosystems.

According to the International Panel for Climate Change (IPCC) [3], the effects of climate change will vary in intensity and time, depending on the region and the type of events. For certain extremes (e.g., floods and droughts), regional projections are more reliable and indicate larger changes than global projections. On the other hand, the risks of climate effects also have spatial and temporal patterns of exposure and vulnerability. Thus, understanding and effectively managing climate-related risks for adaptation largely depends on the potential of regional and local communities to mitigate and adapt, which is disproportionate to the lack of advantages among rural communities [8,9]. In 2014, the latter represented $46 \%$ of the world's population [10], with a high urbanisation rate in the Americas and Europe, while Africa (60\% rural population) and Asia (52\% rural population) are mostly highly vulnerable rural communities [11] that depend for their livelihoods on a 'climate-related risky' type of agriculture, which is expected to be severely affected by climate change [2].

To avoid the risks related to climate change, which could be devastating for vulnerable rural communities, and to meet the food demands of an increasing world population that is expected to reach 10 billion by 2050 [10], the International Panel for Climate Change (IPCC) has repeatedly expressed the importance of using sustainable agriculture to adapt to climate adversity and build the resilience of ecosystems so that they can continue to generate services for our societies [2,12-14]. Other authors have also illustrated the close alignment between sustainable agriculture, ecosystem services, and climate adaptation (e.g., $[15,16])$.

This correlation began to emerge within the scientific community after the WCED (World Commission on Environment and Development) report, known as the Brundtland Report, was released in 1987, parallel to the notion of sustainable development. Yet, this concept has created much ambiguity as to the sustainable development concept [17-19]. Additionally, the resilience concept, which incorporates both general and specific factors and which was originally used in psychology and material sciences, has been increasingly accepted in other disciplines to describe complex socio-ecological systems undergoing continuous mutation [20].

In this research, agrosystem resilience is inspired by Folke et al. [21] and refers to the capacity of agricultural systems to respond to social, economic, and environmental changes via structural reorganization, to offset the impacts of future changes, and to engage in new opportunities, to guarantee continuity for agrosystems. For sustainable agriculture, we adopt the definition given by the Organization for Economic Co-operation and Development (OECD) based on the Brundtland report [22], which states that "sustainable agriculture is agricultural production that is economically viable and does not degrade the environment over the long run" [23]. This type of agriculture has environmental, social, and economic dimensions that must be considered together. According to Ikerd [24], sustainable agriculture must "use farming systems that conserve resources, protect the environment, produce efficiently, compete commercially and enhance the quality of life for farmers and society overall". This mainly requires the implementation of sustainable practices, (the exact definitions of agroecological agriculture, conservation agriculture, and other sustainable practices are reported in the Results section), such as agroecological processes and principles and conservation agriculture, which position agricultural systems at the interface of natural and social systems [25].

Even though the number of recommendations on the use of sustainable agriculture to improve ecosystem services for better resilience to climate change is increasing, no tangible and systematic evidence exists on how this process would participate in alleviating the impacts on vulnerable rural communities. Hence, to remove any scientific ambiguity, based on the definition stated previously, this research will review the efforts made and the results achieved from the date of the first relevant publication (no lower boundary) until the end of 2018, to define an agricultural model that finds a holistic balance between the environment economy and society to understand how, in this changing climate, sustainable agriculture can build the resilience of natural and physical systems. The recommendations highlight the areas where evidence is lacking to address strategic research needs. 


\section{Material and Methods}

Sustainable agriculture is intended to increase the resilience of agrosystems to allow them to keep generating services even during extreme climate events [26,27]. To address this argument, this research has integrated multiple methods employing the ecosystem services framework adopted by the Millennium Ecosystem Assessment (MA), as described in the following sections.

\subsection{Bibliometric Analysis}

The Systematic Review (SR) protocol, which will be described in the next section (Section 2.3), has been adopted for this analysis. The retrieved literature was exported into Mendeley (reference manager software). All the duplicate and spurious results were eliminated, and, before the relevance assessment, the bibliography was analyzed according to a list of indicators, including the source and type of documents, the year of publication, and the subject area. Bibliometric methods are now available in many scientific research methodologies [28] because of the value they add in data interpretation.

\subsection{Concept Network Analysis}

This research also integrated a network analysis [29,30], which has proven to be effective in text analysis. This method is based on a probabilistic assessment of word co-occurrence with relative word position, considering the structural properties of the text itself. This method graphically represents the network relationships between different keywords using qualitative and quantitative metrics [31].

The analysis was developed through different steps [31], beginning with the submission of the text to InfraNodus (https://infranodus.com/), a Web-based analytical engine. First, the text was prepared by removing frequent words to bind it together. The Krovetz Stemmer algorithm then stems the remaining words to reduce their redundancy and complexity [32,33] and further normalizes the text before encoding. InfraNodus converts the submitted text into a network by performing a two-pass analysis. The graphical network can be used to represent the data visually using various software, such as Gephi for visualization and exploration [34].

\subsection{Systematic Review Protocol}

The Systematic Review (SR) methodology is described in the systematic review guidelines developed by the Collaboration for Environmental Evidence as a way to inform practice and policy in environmental management [35]. The formulation of the primary question is the most important aspect in an SR, which (according to Pullin et al. [36]) requires a compromise between different approaches: a holistic approach and a reductionist one. Therefore, the primary research question that covers all the aspects of sustainable agriculture and its role in building resilience to climate change is the following:

"How can Sustainable Agriculture Increase Resilience to Climate Change?"

Following the systematic review conventions, this research question is broken down, as required by the Collaboration for Environmental Evidence (CEE) guidelines, into definable elements known as the PICO/PECO: (a) the population (sustainable agriculture from the date of the first relevant publication onwards; however, this concept began to emerge in the 80s [37], so no location restrictions will be set because this concept could be applied to any agricultural system); (b) interventions (interventions in the expansion of sustainable agriculture have been done since the 1980s, facilitating changes in natural and physical systems); (c) comparators (sustainable agriculture versus conventional agriculture(Conventional agricultural systems are intensive mono-systems based on high input use.)); and (d) outcomes (resiliency parameters to climate change defined as the quantitative/qualitative changes in ecosystem services). The search terms used for this review were used to formulate different search keywords. A trial was undertaken on 18 September 2018 to refine the search terms using the Scopus database. One keyword was adopted for the systematic review after a discussion of the trial results with the co-authors and experts (Table 1). This keyword was used to search the different scientific database sources, as well as the grey literature, which included only English publications. 
All literature retrieved in the first step was screened for relevance according to the previously established inclusion criteria, which included (a) relevant subjects (any country, any spatial scale); (b) the type of intervention (sustainable management); (c) comparators (which compare the benefits and/or impacts on natural and physical systems); (d) methods (modeling, experiments, and surveys); (e) outcomes (studies that consider the benefits/impacts on terrestrial and aquatic ecosystems, hydrology and water resource management, the natural environment, food and fiber production and security, immigration, poverty, human health, human infrastructure, and economic loss).

Table 1. Summary of the search terms used for the question formulation and search keyword structuring.

\begin{tabular}{|c|c|c|c|}
\hline Population & Intervention & Comparator & Outcomes \\
\hline \multirow[t]{8}{*}{$\begin{array}{l}\text { Sustainable } \\
\text { Agriculture }\end{array}$} & Production & Impacts & $\begin{array}{l}\text { Quantitative/qualitative changes in terrestrial and aquatic } \\
\text { ecosystems }\end{array}$ \\
\hline & Expansion & Benefits & $\begin{array}{c}\text { Hydrology and water resource management } \\
\text { natural environment }\end{array}$ \\
\hline & & & Food and fiber production and security \\
\hline & & & Immigration \\
\hline & & & Poverty \\
\hline & & & Human health \\
\hline & & & Human infrastructure \\
\hline & & & Economic loss \\
\hline Keyword & \multicolumn{3}{|c|}{$\begin{array}{l}\text { "sustainable agriculture" AND "resilience" AND "climate change" AND (agroecol OR ecosystem } \\
\text { OR conservation OR integrat OR rotation OR diversification OR organic OR water OR environment } \\
\text { OR food OR fiber OR immigration OR poverty OR health OR infrastructure OR income) }\end{array}$} \\
\hline $\begin{array}{l}\text { Number of Hits } \\
\text { on Topic }\end{array}$ & \multicolumn{3}{|r|}{2172} \\
\hline
\end{tabular}

\section{Results}

The 3563 records gathered from the scientific databases, and the grey literature, were retrieved using the Mendeley software (Table 2). After cleaning and removing duplicates, a total of 2671 documents remained, and a bibliographic analysis was carried out, followed by first filtering based on the title of the literature, followed by using the Network analysis method to map the titles and keywords of all documents that passed the filtering process. This systematic review approach consisted of reviewing the full-text of the filtered documents based on the inclusion criteria and the 'outcome' search terms. This process was carefully and transparently documented and has been schematically summarized for simplification according to the following diagram (Figure 1).

Table 2. Sources of the literature retrieved by the database and the corresponding number of records.

\begin{tabular}{ccc}
\hline Database & Number of Records & Notes \\
\hline Scopus & 2351 & All records were retrieved \\
Science Direct & 854 & All records were retrieved \\
ISI Web of Science & 203 & All records were retrieved \\
DOAJ & 13 & All records were retrieved \\
Grey Literature * (Google, Websites, etc.) & 142 & The first 50 records were retrieved \\
Total & 3563 & \\
\hline
\end{tabular}

* The first 50 records were retrieved because the following were assessed and agreed to be repetitive or irrelevant. 


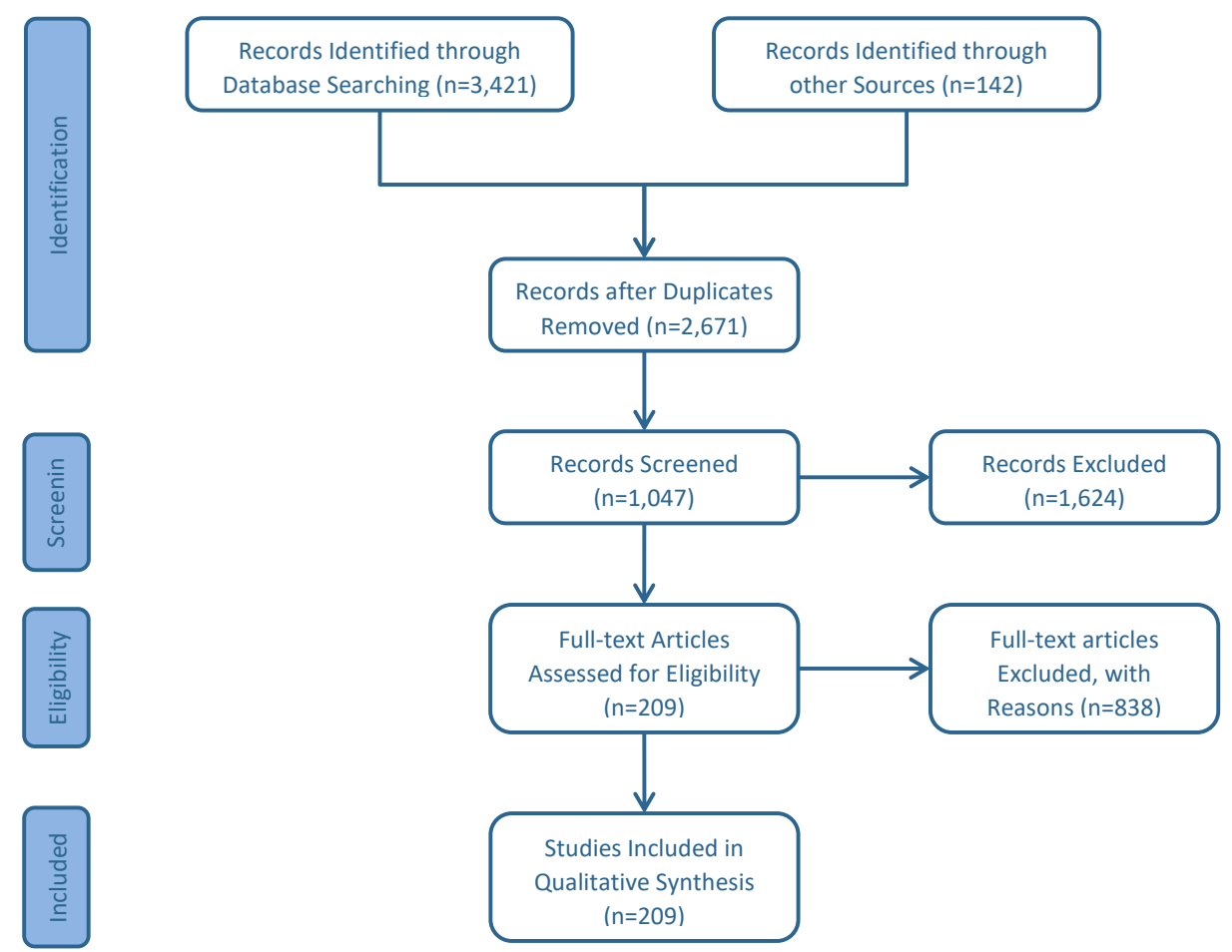

Figure 1. Flow Diagram of the research process (after Moher [38]).

\subsection{Bibliometric Analysis}

The date of the first relevant publication capturing the question subject to this research was the mid-nineties, even though sustainability as a concept was first discussed in the eighties. This analysis shows that most of the documents feature restricted access, with a slight increase in open-access publications from 2010 onward (Figure 2). The United States offers the most publications, with Australia, China, and many European countries among the top 10 countries that published 56.5\% of the relevant research during our study's timeframe (Figure 3). Three major subject areas were identified, for which $68.9 \%$ of the documents retrieved are classified, including environmental science, agricultural and biological sciences, and social sciences. Minor subject areas, according to the analysis, include Earth and planetary science, engineering, chemistry, and others (Figure 4 ). Finally, $61.8 \%$ of the documents retrieved were research articles, and $14.8 \%$ were review papers, while books, book chapters, and conference papers were fewer in number (Figure 5).

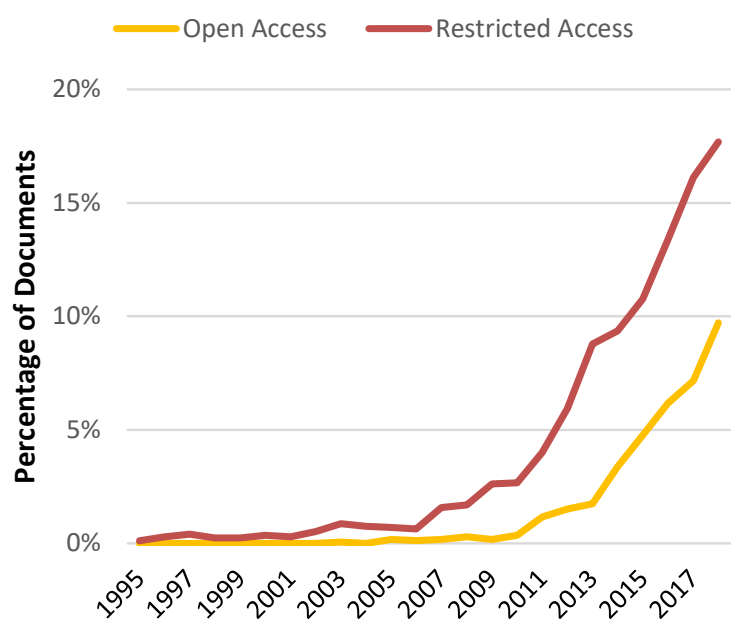

Figure 2. Percentage of documents retrieved by year and access type. 


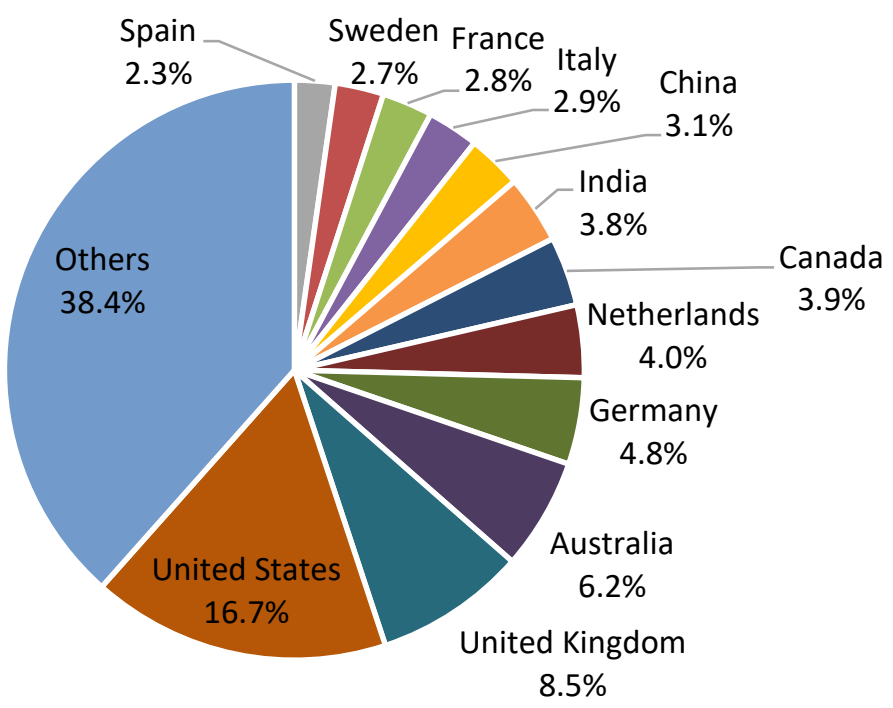

Figure 3. Percentage of documents retrieved by country of publication.

Environmental Science

Agricultural and Biological Sciences

Social Sciences

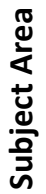

Earth and Planetary Sciences

Engineering

Energy

Economics, Econometrics and...

Others

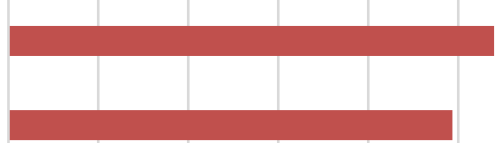

(n) 


\subsection{Concept Network Analysis}

As already anticipated, by the end of the second filtering process, the Infranodus Web-based analytic engine had analyzed and mapped the titles and keywords (combined in one graph) of the publications selected for the final review in this research.

This analysis identified the 'most influential words' and the main topics of the assessed texts (titles and keywords) and suggested a correlation between them in the form of 'a question to ask', which highlighted this relationship (Table 3). Mapping the text (Figure 6) emphasized the results summarized in the table, which allows us to make the following observations:

- While the network has several perspectives, its combined structure is focused. This analysis identified a possible connection between the topics "agriculture-conservation-climate" and "crop-system-production" in the combined network (Figure 6).

- There was a very high consistency between the results of the combined contexts (91\% similarity for the most influential elements), which validates the filtering process.

- The influential words highlight the importance of crop systems and soils, which means that most of the literature focuses only on soil quality and health while neglecting other ecosystem services. This can be justified, according to Doran [39], by the fact that soil quality and health is the primary indicator for sustainable management and is vital to the functioning of the global ecosystem.

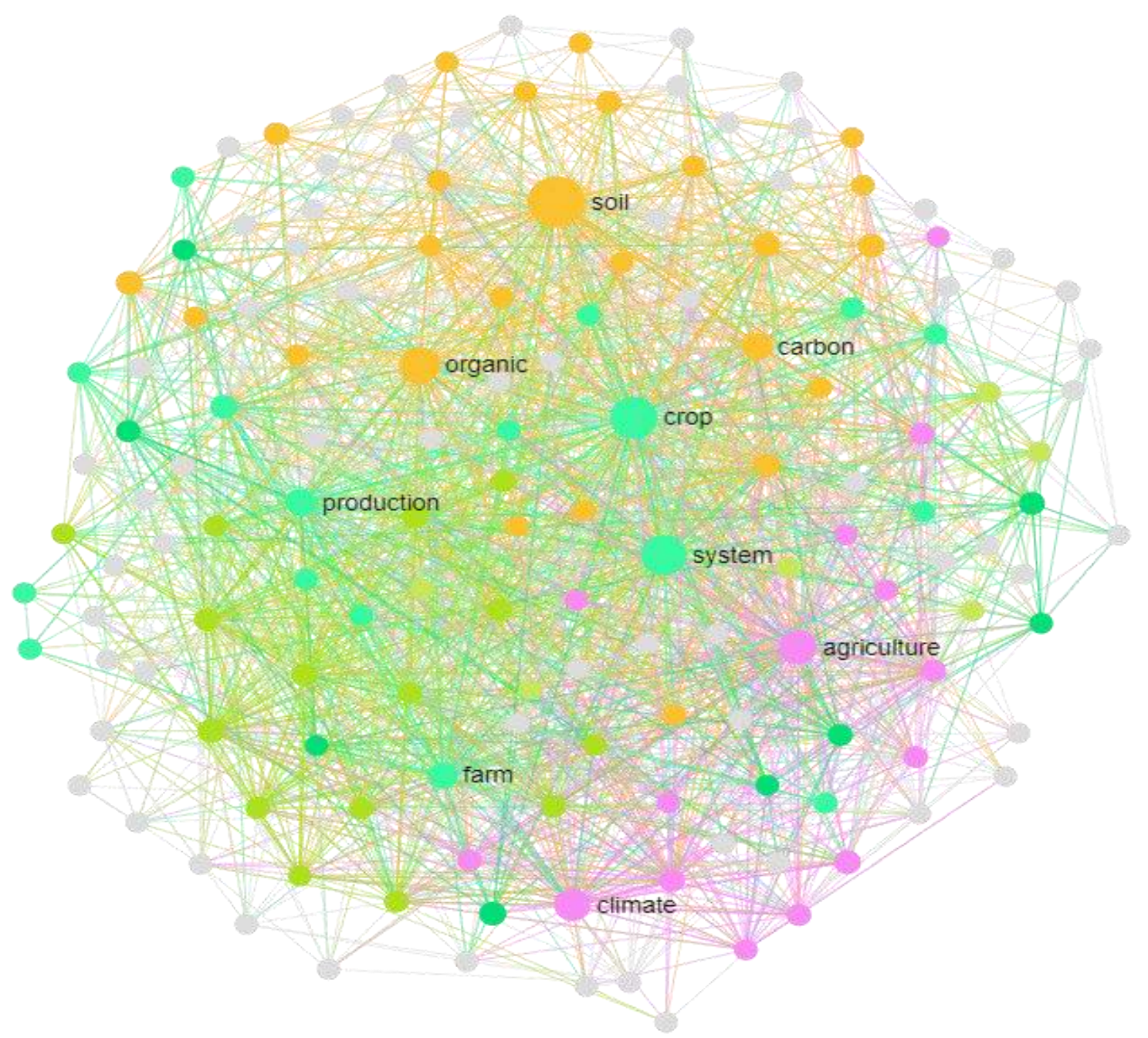

Figure 6. Combined concept network map for the titles screened for the final review and the corresponding keywords. 
Table 3. Synthetic report of the network analysis generated by combining titles and keywords using the Infranodus software.

\begin{tabular}{|c|c|c|c|}
\hline Context & Influential Words & Main Topics & Question to Ask \\
\hline \multirow[t]{2}{*}{$\begin{array}{l}\text { Combined } \\
\text { (Titles }+ \\
\text { Keywords) }\end{array}$} & $\begin{array}{l}\text { crop, soil, system, } \\
\text { organic (highest between } \\
\text { titles and keywords) }\end{array}$ & $\begin{array}{ll}\text { 1. } & \text { soil, organic, water } \\
\text { 2. } & \text { resilience, food, sustainable } \\
\text { 3. } & \text { crop, system, farm } \\
\text { 4. } & \text { agriculture, } \\
& \text { conservation, climate }\end{array}$ & $\begin{array}{l}\text { What is the relationship between } \\
\text { "agriculture-conservation-climate" } \\
\text { and "crop-system-farm"? }\end{array}$ \\
\hline & \multicolumn{3}{|c|}{$\begin{array}{c}\text { Network structure: A total of } 150 \text { nodes, } 0.3 \text { modularity, } 32 \% \text { of words in the top topic (a total of } 6 \\
\text { topics), } 100 \% \text { in the main connected component ( } 1 \text { in total), influence dispersal } 50 \% \text {. } \\
\text { Network diversity level: focused }\end{array}$} \\
\hline
\end{tabular}

\subsection{Systematic Review Protocol}

According to the literature, sustainable agriculture is a group of multi- or transdisciplinary agricultural practices that apply ecological principles to agricultural systems e.g., [40-42] to harness ecosystem services and to contribute to agriculture's resilience to extreme climatic events [15]. These practices are numerous and can be location-specific and associated with local farming conditions $[16,43]$. For instance, Harvey [44] identified 3.8 ecosystem-based practices (Ecosystem-based agriculture is a group of practices, which, according to Altieri and Koohafkan [45], could improve all ecosystem services (provisioning, regulating, habitat, and cultural), and thereby, contribute to human well-being) per farm in six central American landscapes that could be location-specific and associated with local farming conditions [16,43]. Therefore, different practices generate different trade-offs.

The list of sustainable agricultural practices could continue, as many different ecosystems are managed by different communities. To simplify the systematic review results, we classified the assessed practices into eight different categories: integrated management, soil management, crop management, landscape management, water management, genetic management, biodiversity management, and knowledge management (Table 4). Further, this review was based on a narrative synthesis, which is more suited to studies with broad subject content and a disparate range of outcomes. 
Table 4. Categorized practices for sustainable agriculture .

\begin{tabular}{|c|c|c|c|c|}
\hline Category & Agricultural Practices $^{+}$ & $\mathbf{N}^{\circ}$ of Reviewed Documents & Impact ${ }^{*}$ & $\begin{array}{c}\text { Sustainability } \\
\text { Dimensions } \ddagger, \zeta, \mathrm{b}\end{array}$ \\
\hline & Soil Management & 49 & Mostly Positive & \multirow{4}{*}{ 1D (24); 2D (25) } \\
\hline & Amendments (Biochar use, manure, etc.) & 27 & $+(24) ; \pm(3)$ & \\
\hline & Tillage Practices & 20 & $\begin{array}{l}+(17) ; \pm(3) \\
\end{array}$ & \\
\hline & Mulching Techniques & 5 & $+(4) ; \pm(1)$ & \\
\hline & Crop Management & 29 & Mostly Positive & \multirow{8}{*}{ 1D (14); 2D (13); 3D (2) } \\
\hline & Crop Rotation & 15 & $+(13) ; \pm(2)$ & \\
\hline & Intercropping & 9 & $+(8) ; \pm(1)$ & \\
\hline & Cover Crop & 3 & $+(2) ; \pm(1)$ & \\
\hline & Residue Management & 2 & $+(2)$ & \\
\hline & Plant bio-regulators (PBRs): e.g., stimulants, elicitors & 3 & $+(3)$ & \\
\hline & Plant Growth-Promoting Microbes (PGPM) & 4 & $+(4)$ & \\
\hline & Landscape Management & 17 & Mostly Positive & \\
\hline & Landscape ecology design and management & 0 & & \multirow{6}{*}{$1 \mathrm{D}(10) ; 2 \mathrm{D}(5) ; 3 \mathrm{D}(2)$} \\
\hline & Land fragmentation & 0 & & \\
\hline & Agroforestry & 9 & $+(8) ; \pm(1)$ & \\
\hline & Trees Plantation & 4 & $+(4)$ & \\
\hline & Traditional Systems & 4 & $+(3) ; \pm(1)$ & \\
\hline & Water Management & 8 & Mostly Positive & \\
\hline & Irrigation Regimes & 0 & & \multirow{6}{*}{$1 \mathrm{D}(3) ; 2 \mathrm{D}(3) ; 3 \mathrm{D}(2)$} \\
\hline & Water Harvesting & 4 & $+(3) ; \pm(1)$ & \\
\hline & Water-Saving & 3 & $+(2) ; \pm(1)$ & \\
\hline & Water Reuse & 0 & & \\
\hline & Unconventional Water & 2 & $\pm(1) ;-(1)$ & \\
\hline & Genetic Management & 9 & Mostly Positive & \\
\hline & High-quality seeds and planting materials & 0 & & \multirow{5}{*}{$1 \mathrm{D}(8) ; 2 \mathrm{D}(3)$} \\
\hline & Adapted and native varieties & 0 & & \\
\hline & Crop/Cultivar Diversity & 11 & $+(9) ; \pm(2)$ & \\
\hline & Breeding and genetic technologies & 0 & & \\
\hline & Microbiome science & 0 & & \\
\hline & Biodiversity Management & 5 & All Positive & \multirow{5}{*}{$1 \mathrm{D}(5)$} \\
\hline & Agro-ecology & 3 & $+(3)$ & \\
\hline \multicolumn{5}{|c|}{ Ecosystem-based approaches } \\
\hline & Pollination management & & & \\
\hline & Community biodiversity management (CBM) & 1 & $+(1)$ & \\
\hline & Functional Agrobiodiversity & 1 & $+(1)$ & \\
\hline & Ecological Intensification & & & \multirow{5}{*}{$1 \mathrm{D}(4) ; 2 \mathrm{D}(2)$} \\
\hline & Knowledge Management & 6 & All Positive & \\
\hline & Meteorological Forecast & 1 & $+(1)$ & \\
\hline & Indigenous/Traditional Knowledge Systems (IKS) & 4 & $+(4)$ & \\
\hline & Knowledge Sharing & 1 & $+(1)$ & \\
\hline
\end{tabular}


Table 4. Cont.

\begin{tabular}{|c|c|c|c|c|}
\hline Category & Agricultural Practices $^{+}$ & $\mathbf{N}^{\circ}$ of Reviewed Documents & Impact * & $\begin{array}{c}\text { Sustainability } \\
\text { Dimensions } \ddagger, c, \mathrm{~B}\end{array}$ \\
\hline & Integrated Management & 86 & Mostly Positive & \multirow{11}{*}{ 1D (35); 2D (42); 3D (9) } \\
\hline & Integrated Agricultural Systems (IAS) & 17 & $+(14) ; \pm(2) ;-(1)$ & \\
\hline & Organic agriculture (OA) & 20 & $+(18) ; \pm(1) ;-(1)$ & \\
\hline & System of Crop Intensification (SCI) & 19 & $+(9) ; \pm(7) ;-(3)$ & \\
\hline & Climate-smart agriculture (CSA) & 10 & $+(8) ; \pm(1) ;-(1)$ & \\
\hline & Extensive Systems (ES) & 2 & $+(2)$ & \\
\hline & Other integrated practices ${ }^{\ddagger}$ & 2 & $+(2)$ & \\
\hline & Integrated Natural Resources Management (INRM) & 28 & $+(24) ; \pm(3) ;-(1)$ & \\
\hline & Nature-Based Solutions (NBSs) & & & \\
\hline & Natural System Agriculture (NSA) & & & \\
\hline & Diversified Farming Systems (DFS) & & & \\
\hline
\end{tabular}

The number of documents per category might differ from the sum of the reviewed papers per agricultural practice because some documents might have assessed more than one agricultural practice in the same category. * A positive impact is any improvement in the indicators assessed in each study belonging to any sustainability dimension. ${ }^{\zeta}$ This refers to the sustainability dimensions that have been assessed in each study (economic, environmental and social), e.g., if a study assessed soil biological activity, it is considered one dimensional (1D), if it assessed both soil biological activity and yield, it is considered two dimensional (2D). ${ }^{\dagger}$ Agricultural practices with 0 reviewed papers mean the a) such practices were mentioned in the literature as sustainable practices but were not caught by the primary question or $b$ ) these practices have been studied in combination with other practices, and their count is included under 'other integrated practices'. ‡ ‘Other integrated practices include combined practices from different categories. 


\subsubsection{Integrated Management}

Many integrated farm management methods exist in the literature, but not all of them emerged using the research question adopted in this review. Thus, the large number of papers included in this category is mainly due to two facts: (a) A significant portion of the studies included in this management category features the integration of two or more practices belonging to different categories and were added under this category to prevent replication in the analysis. Given the diversity of the approaches implemented to assess these studies, it was challenging, in most cases, to isolate the impacts of these single practices and evaluate them. However, the overall impacts were positive (Supplementary Materials). (b) The other portion of the documents reviewed features the consolidated methods mentioned in the literature with recognized principles and respected rules (i.e., Conservation Agriculture (CA), Sustainable Intensification (SI), Integrated Agricultural Systems (IAS), and Organic Agriculture (OA)).

Conservation Agriculture is a method that involves three main principles [46]: (a) soil management to reduce the soil's physical disturbance and its degradation; (b) crop management, such as residue management, to protect the soil's top layers; and (c) genetic management to increase the agricultural systems' biodiversity and thus, their resilience. In general, the documents reviewed showcase the importance of Conservation Agriculture (Supplementary Materials), especially under extreme climate conditions (e.g., [47,48]). Sommer [49] was the only exception, demonstrating instead that CA can merely slow the loss of soil organic carbon over time.

Sustainable Intensification (SI) includes the System of Crop Intensification (SCI) method and is another method that uses sustainable practices to safeguard natural resources and meet the growing demand for agricultural production, considering the three sustainability dimensions to build resilience [50,51]. To reach this objective, the concept of Sustainable Intensification is established in four fields of action [52]: (1) agronomic development, (2) resource use efficiency, (3) land use allocation, and (4) regional integration. In practice, this study detected a few documents that relate Sustainable Intensification to resilience and climate change. These works used different assessment criteria and diverse indicators (e.g., change in yields, gas emissions, etc.) to generate positive externalities (Supplementary Materials), which could be (according to Ares [53]) comparable to the externalities generated by Conservation Agriculture.

The low diversity of conventional systems has led to degradation and has reduced the ecosystem services traditionally supplied by agriculture [54]. The Integrated Agricultural System is a model promoted internationally for its relevance (as well as related concepts) in increasing farm diversity and lowering reliance on external inputs, enhancing nutrient cycling, and increasing natural resource use efficiency $[55,56]$. This study screened several documents that assessed the impacts of IAS in terms of economic benefits, environmental efficiency, and social aspects studied individually (Supplementary Materials); all factors confirmed the positive impacts of this concept. The studies that evaluated the three sustainability dimensions combined (using qualitative methods) also generated positive impacts $[57,58]$.

Organic Agriculture (OA) is another integrated production method, which, according to IFOAM-Organics International, sustains soil health, ecosystems, and people based on four principles: health, ecology, fairness, and care [59]. The assessed literature acknowledges the importance of Organic Agriculture in improving the ecology and biodiversity of agriculture systems and reducing social, economic, and environmental risks (Supplementary Materials). However, there is evident disagreement within the scientific community on the potential of this practice to guarantee high levels of food security. From one perspective, a portion of the literature reports a considerable reduction in yields observed in organic agricultural systems [60-64]; however, other literature maintains, based on trials, that the achieved yields are comparable to those of conventional systems [65-68]. This divergence in output is explained by Seufert [69], who reviewed the performance of Organic Agriculture in the literature and showed that it could have, in some cases, higher yields compared to conventional agriculture; however, in other cases, the yields are significantly lower or insignificantly lower (statistically). The authors 
pointed out that variability in yields highly depends on the crop variety and socio-economic conditions in the case study [69]. Finally, when convergence in results was observed in average climate years, Organic Agriculture overweighed conventional agriculture in extreme weather years $[67,70]$, which makes this integrated method very efficient for agricultural resilience.

The concept of Climate-Smart Agriculture (CSA) emerged in 2009 as a potential approach to capture the synergy between agricultural adaptation and mitigating climate change [71,72]. CSA is currently lively debated in this regard. Apart from the studies that the Food and Agriculture Organization of the United Nations directly or indirectly publishes (e.g., [43,73-75]), which all show encouraging results, two recent documents screened in this review both assessed the impacts of Climate-Smart Agriculture on the resilience of agriculture and have shown positive results in terms of yields, the concentration of inputs, and resource use efficiency [76,77].

Other methods have been mentioned in the literature (e.g., Natural System Agriculture (NSA), Integrated natural resource management (INRM), etc.), but had not been studied or assessed in relation to resilience and climate change sufficiently to be retrieved for this review.

\subsubsection{Soil Management}

Soil quality and health are considered a key indicator of sustainable management because the assessment criteria integrate ecosystem processes, climate variables, and physical, chemical, and biological properties. This explains the growing interest in soil management for more sustainable agriculture. This focus is expressed in the total amount of reviewed publications (69 out of 209) that analyzed the impacts of sustainable agriculture on soil quality and health, without including the number of documents assessing the relationship between soil management and sustainable agriculture that were classified under the 'Integrated Management' category (Table 3) because they were combined with other practices, such as tillage practices with different irrigation regimes and crop diversity with improved seeds (Supplementary Materials).

The methods and practices for soil management vary from soil amendments (biochar, litter, compost, and manure) to tillage practices (zero tillage, minimum tillage, etc.) and mulching techniques. Even though soil management is one of the most intensively studied and best-documented categories, this review showed inconsistency in the methodologies adopted and the indicators selected for the relevant assessments. The research focus was divided between biological, physical, and chemical characteristics; within each characteristic, the indicators were very different. For instance, Supplementary Materials includes many soil quality indexes that differed from one study to another, such as cation exchange capacity (CEC), sodium adsorption ratio (SAR), electric conductivity (EC), available and/or total phosphorus and nitrogen, microbial biomass carbon (MBC), total organic carbon (TOC), soil organic carbon (SOC), soil organic matter (SOM), etc. [78-83]. Biological activity can be evaluated via the nematode communities in soils (e.g., [84]), through bacterial and fungal diversity (e.g., [85]), or even through enzymatic activity (e.g., [86]). Physical indicators included soil porosity, soil compaction, soil erosion index, hydraulic conductivity, holding capacity, etc. (e.g., [87-91]).

Despite the differences in methodologies and indicators, the practices assessed (i.e., tillage practices, mulching techniques, and soil amendments) showed positive impacts on soil quality and health. These impacts were more pronounced under extreme weather conditions [92-95]. However, the reference system, in comparison, must be carefully selected [96]. For instance, comparing the impacts of organic amendments on yield increases when the control is a high input system would not favor of organic amendments.

Very few studies (Table 4), impact sign $( \pm)$ ) have emphasized the dependence of outcomes for crop type, soil type, climate, and weather conditions (e.g., [87]). Some studies have raised awareness about the no-till practice, which is confirmed to increase top-soil organic carbon, noting that this increase in not always translated into improved crop growth due to the larger concentrations near the surface [97,98]. Notably, none of the documents included under the 'soil management' category adopted an ecosystem-based approach, which is defined as an adaptation strategy to the adverse 
effects of climate change [99-101]. Likewise, no studies assessed all three dimensions of sustainability (environmental, social, and economic pillars).

\subsubsection{Crop Management}

This category is the second after soil management in terms of the number of documents studied and screened for the review. This category includes several practices to manage crops in the field, such as crop rotation, cover crop, intercropping, residue management, and different techniques to stimulate crop resistance and growth, such as plant bioregulators and plant growth-promoting microbes. The latter has recently received considerable scientific attention to validate their bio-stimulation and growth properties in plants.

The practices and techniques in this review were studied via different methodologies with different outputs, but all had positive results, which confirms the importance of crop management for improving agricultural system sustainability. Acknowledging the benefits that these techniques and practices generate, Roberts and Mattoo [26] doubted whether crop management could produce yields like current production patterns. Other studies, however, have noted the importance of these techniques, especially in extreme weather conditions [102-106], which suggests that crop management could, under future climate conditions, outweigh the current production systems and thus increase resilience.

Nevertheless, the inability to assess crop management via the three dimensions of sustainability (environmental, economic, and social) indicates that research in this field has not yet reached an interdisciplinary level that can reflect the sustainability of the whole agricultural system. Only two recent review studies assessed the available literature (Supplementary Materials)—one on intercropping practices and one on plant growth-promoting microbes on a three-dimensional structure - to demonstrate that the appropriate implementation of these practices and techniques could facilitate a balance between productivity, resilience, and environmental health $[107,108]$.

\subsubsection{Landscape Management}

The landscape management of production systems, which was recognized by FAO (The Food and Agriculture Organization of the United Nations) [109] as an integrated and multidisciplinary approach to generate ecosystem services, has recently emerged in the literature under different principles and practices, such as agroforestry [110], tree plantations, and traditional systems that are used to contribute to increasing the sustainability of agricultural systems and their resilience to climate change. Several documents have analyzed the effects of some landscape practices on the sustainability of production systems (Supplementary Materials); most of them show the positive impacts that could be greater under extreme climate conditions [111]. Two scientific papers adopted an ecosystem-based approach to assess the sustainability of traditional systems (Supplementary Materials): One research paper studied irrigation systems in New Mexico [112], and one review paper qualitatively considered the impacts of traditional terracing on ecosystem services [113].

\subsubsection{Water Management}

The limited number of papers dealing with water management screened do not reflect the total number of water management papers in the databases, but this limitation does highlight the absence of an ecosystem-based approach to assess water management and determine the impacts on the different services in agrosystems. Moreover, some water management methods have been assessed in combination with other management methods and different agricultural practices. Even though the impacts of these combined methods were positive, the single impacts of water management are not easily separated from the overall impacts of the integrated management practices (Supplementary Materials).

Therefore, the available literature primarily assesses methods, such as water harvesting, water-saving techniques, unconventional water sources, and irrigation regimes, based on one or two aspects of the sustainability dimensions. The three sustainability pillars (economic, social, 
and environmental) were not considered, except for two review studies that evaluated the literature published on rainwater harvesting, which reported the positive impacts of this practice on different ecosystem services [114,115]. Excluding one study by Martin-Gorriz [116], which concluded that the use of alternative water-based techniques, such as water desalination, reduces the resilience of agricultural systems by consuming more energy and participating in GHG emissions, the results of the assessed documents generally show positive impacts (Supplementary Materials).

\subsubsection{Genetic Management}

In this category, we excluded genetically modified organisms due to their direct and indirect environmental implications and alleged impacts on human health, despite their enhanced yield potential [117,118].

Even though breeding is expected to confer higher resilience to agroecosystems, Lammerts van Bueren [119] reviewed the current findings on plant breeding and concluded that all plant breeding orientations adopted to date (i.e., corporate-, community-, ecosystem-, and trait-based-breeding) do not facilitate sustainable agriculture. These authors suggested using a systems-based breeding approach to participate in developing resilient, sustainable agriculture.

Under this category, two practices were found in the literature: crop diversity and cultivar diversity. Both practices generated positive results in terms of the resilience of agroecosystems and household food security (due to diet diversification), soil quality, and other environmental aspects (i.e., disease control and predator abundance). However, there is disagreement in the literature about the impacts of genetic management on yield increases. While some authors argue that crop and cultivar diversity is positively and significantly related to production [120-122], others maintain that a productivity increase is observable only in normal years, not during extreme weather events or epidemics [123]. Notably, most of the research documenting the benefits of diversification evaluated a single ecosystem service [124].

\subsubsection{Biodiversity Management}

Methods, such as agroecology, agrobiodiversity, and ecological intensification, which apply ecological principles to agriculture, have been investigated for the last few decades to promote synergy between biodiversity and the social aspects of agrosystems. The papers assessed in this review show positive results (Supplementary Materials). However, these assessments focused on environmental aspects. Calderón [125], on the other hand, indicated that agroecology-based farmers in Guatemala have higher levels of food availability than semi-conventional farmers during extreme weather seasons.

\subsubsection{Knowledge Management}

Knowledge management is, according to Newman and Conrad [126], "an integration of numerous endeavors and fields of study", which makes it complicated to define. Based on the latter study and the efforts made by Boom [127] to define knowledge management, we adopt in this research the following definition: "A process to improve the performances of individuals, organizations, and systems, and to generate value from intellectual and knowledge-based assets". This definition includes both tacit and explicit knowledge, the former being based on experiences (e.g., indigenous, local, and traditional knowledge) and the latter being recorded in the literature [128]. Both types of knowledge have been recognized as fundamental to build resilience to climate change and contribute to sustainable development [13]. However, to share knowledge and achieve adaptation, a transfer strategy is essential to transfer knowledge from a tacit to an explicit form [129].

Knowledge management for agricultural system resilience is a recent development in the literature, which explains the limited number of relevant studies. The major research topics include indigenous and traditional knowledge systems, with only two studies on meteorological information and knowledge sharing; all relevant studies confirmed the importance of these practices for agrosystem resilience (Supplementary Materials). These results are a step forward to achieve knowledge transfer and sharing 
for climate resilience, as suggested previously, as these results transform the nature of indigenous and traditional knowledge from tacit to explicit. However, to enhance resilience and facilitate sustainable agriculture, more efforts should be made to improve our understanding of traditional knowledge for building synergy using scientific knowledge [130,131].

\section{Discussions and Recommendations}

Several observations have emerged from the results of this systematic review. Next, we discuss the observations and make some recommendations for the scientific community and policymakers in sustainable agriculture-related areas.

Sustainability is a three-dimensional model that requires a change in practice to contravene disciplinary boundaries, thereby realizing transdisciplinarity [132], which represents a step forward for interdisciplinarity towards full integration. This goal is far from being achieved, according to Brandt [133], and this review has further demonstrated that, in agriculture, we have not yet reached a level of interdisciplinarity where the knowledge and methods from different disciplines are unified into a synthetic approach.

The results confirm that different management aspects are commonly studied separately, which means that the literature has not studied sustainable agriculture as a whole but merely some practices and technologies that participate in sustainable agriculture, mainly through the improvement of system biodiversity and ecosystem services [14]. To cope with the challenges of sustainable agriculture, changes in management strategies must be based on the integration of all management categories (Table 4) to produce a unique management method for agrosystems that accounts for soils, water, crops, genetics, the landscape, biodiversity, and knowledge and uses unified quantitative methods for evaluation and assessment.

The ecosystem-based approach described earlier in the paper is the most effective tool to achieve integration for the sustainable management of agrosystems under climate change because it is based on the management of all ecosystem processes and services, thereby improving the ability of crops to maintain their yields [99-101]. This is to be done on a life cycle basis and has been successfully applied in the literature to agro-food systems (e.g., $[134,135]$ ) because it considers the interactions between resource use and potential impacts on biodiversity $[136,137]$. Finally, climate change impacts and resilience of agrosystems are highly dependent on local conditions (environmental, socio-economic, and management), which complicates the process of quantifying sustainable agriculture [138]. Therefore, our recommendations are as follows:

- The integration of all agrosystems services into sustainable management using an ecosystem-based approach on a life-cycle basis via the Life Cycle Assessment (LCA(Life-cycle assessment, or LCA, is an environmental accounting and management approach that considers all the aspects of resource use and environmental releases associated with an industrial system from the cradle to the grave [139].)) method;

- Improving the scientific understanding of traditional knowledge for greater synergy and further integration;

- The unification of assessment methods and indicators for the quantification of impacts;

- The creation of a platform to share, monitor, screen, and approve the assessments and evaluations of sustainable agriculture by region.

\section{Conclusions}

The number of papers in scientific databases that include "sustainable agriculture" is very impressive, constituting almost $10 \%$ of the total "agriculture" papers on 'Scopus' (28,509 out of 283,593 papers on 13 February 2019). This systematic review analyzed sustainable agriculture and its impacts on agrosystem resilience under climate change. The results demonstrate that only single practices and methods have been studied to assess the impacts on single ecosystem services. Although the 
assessed practices and methods have shown to improve agrosystems (mainly their environmental aspects) and make them more resilient to extreme climate events, we are still far from interdisciplinary and multi-dimensional agriculture that integrates all management aspects and generates a full range of ecosystem services.

The recommendations of this study are addressed to the scientific community to help orient their future research strategies and efforts to produce sustainable agriculture under climate change conditions and to policymakers who design and finance such strategies.

Supplementary Materials: The following are available online at http://www.mdpi.com/2071-1050/12/8/3119/s1.

Author Contributions: The authors have contributed equally to the conception, realization and publication of this research. All authors have read and agreed to the published version of the manuscript.

Funding: This research was supported by CURE-Xf, an EU-funded project, coordinated by CIHEAM Bari (H2020-Marie Sklodowska-Curie Actions-Research and Innovation Staff Exchange. Reference number: 634353).

Conflicts of Interest: The authors declare no conflict of interest.

\section{References}

1. WMO. Proceedings of the World Climate Conference. In The World Meteorological Organization (WMO)-N $N^{\circ} 537$; WMO: Geneva, Switzerland, 1979; p. 791. Available online: www.environmentalevidence.org/Documents/ Guidelines/Guidelines4.2.pdf (accessed on 28 February 2019).

2. IPCC. Climate Change 2001: Synthesis Report. A Contribution of Working Groups I, II, and III to the Third Assessment Report of the Intergovernmental Panel on Climate Change (IPCC); Watson, R.T., The Core Writing Team, Eds.; Cambridge University Press: Cambridge, UK; New York, NY, USA, 2001; p. 398.

3. IPCC. Managing the Risks of Extreme Events and Disasters to Advance Climate Change Adaptation. A special report of Working Groups I and II of the Intergovernmental Panel on Climate Change (IPCC); Field, C.B., Barros, V., Stocker, T.F., Qin, D., Dokken, D.J., Ebi, K.L., Mastrandrea, M.D., Mach, K.J., Plattner, G.-K., Allen, S.K., et al., Eds.; Cambridge University Press: Cambridge, UK; New York, NY, USA, 2012; p. 582.

4. Douville, H.; Chauvin, F.; Planton, S.; Royer, J.-F.; Salas-Mélia, D.; Tyteca, S. Sensitivity of the hydrological cycle to increasing amounts of greenhouse gases and aerosols. Clim. Dyn. 2002, 20, 45-68. [CrossRef]

5. Hansen, J.W. Realizing the potential benefits of climate prediction to agriculture: Issues, approaches, challenges. Agric. Syst. 2002, 74, 309-330. [CrossRef]

6. Barnett, T.P.; Adam, J.C.; Lettenmaier, D.P. Potential impacts of a warming climate on water availability in snow-dominated regions. Nature 2005, 438, 303-309. [CrossRef] [PubMed]

7. UNISDR. Global Assessment Report on Disaster Risk Reduction. Revealing Risk, Redefining Development; United Nations International Strategy for Disaster Reduction (UNISDR): Geneva, Switzerland, 2011; p. 178.

8. Hughes, L.; Rickards, L.; Steffen, W.; Stock, P.; Rice, M. On the Frontline: Climate Change E Rural Communities; Climate Council of Australia Ltd.: Sydney, Australia, 2016; p. 95.

9. Ofoegbu, C.; Chirwa, P.; Francis, J.; Babalola, F. Assessing vulnerability of rural communities to climate change: A review of implications for forest-based livelihoods in South Africa. Int. J. Clim. Chang. Str. 2017, 9. [CrossRef]

10. UN. World Urbanization Prospects: The 2014 Revision, Highlights; ST/ESA/SER.A/352; Department of Economic and Social Affairs, Population Division, United Nations (UN): New York, NY, USA, 2015; p. 27.

11. UNFCCC. Reducing Vulnerability to Climate Change, Climate Variability and Extremes, Land Degradation and Loss of Biodiversity: Environmental and Developmental Challenges and Opportunities; United Nations Framework Convention on Climate Change (UNFCCC): Rio de Janeiro, Brazil; New York, NY, USA, 2011; p. 47.

12. IPCC. Climate Change 1995-Impacts, Adaptations and Mitigation of Climate Change: Scientific-Technical Analyses. Contribution of Working Group II to the Second Assessment Report of the Intergovernmental Panel on Climate Change (IPCC); Houghton, J.J., Meiro Filho, L.G., Callander, B.A., Harris, N., Kattenberg, A., Maskell, K., Eds.; Cambridge University Press: Cambridge, UK; New York, NY, USA, 1996; p. 876.

13. IPCC. Climate Change 2014: Synthesis Report. Contribution of Working Groups I, II and III to the Fifth Assessment Report of the Intergovernmental Panel on Climate Change (IPCC); Pachauri, R.K., Meyer, L.A., Eds.; IPCC: Geneva, Switzerland, 2014; p. 151. 
14. IPBES. Global Assessment Report on Biodiversity and Ecosystem Services. The Intergovernmental Science-Policy Platform on Biodiversity and Ecosystem Services (IPBES). 2019. Available online: https://ipbes.net/global-assessment (accessed on 1 April 2020).

15. Maia, A.G.; Miyamoto, B.C.B.; Garcia, J.R. Climate change and agriculture: Do environmental preservation and ecosystem services matter? Ecol. Econ. 2018, 152, 27-39. [CrossRef]

16. Wall, E.; Smit, B. Climate change adaptation in light of sustainable agriculture. J. Sustain. Agric. 2005, 27, 113-123. [CrossRef]

17. Culleton, N.; Tunney, H.; Coulter, B. Sustainability in Irish agriculture. Irish Geogr. 1994, 27, 36-47. [CrossRef]

18. Kuhlman, T.; Farrington, J. What is sustainability. Sustainability 2010, 2, 3436-3448. [CrossRef]

19. Giovannoni, E.; Fabietti, G. What is sustainability? A review of the concept and its applications. In Integrated Reporting: Concepts and Cases that Redefine Corporate Accountability; Busco, C., Frigo, M.L., Riccaboni, A., Quattrone, P., Eds.; Springer Nature Switzerland AG: Basel, Switzerland, 2014; pp. 21-40. [CrossRef]

20. Urruty, N.; Tailliez-Lefebvre, D.; Huyghe, C. Stability, robustness, vulnerability and resilience of agricultural systems. A review. Agron. Sustain. Dev. 2016, 36, 15. [CrossRef]

21. Folke, C.; Carpenter, S.R.; Walker, B.; Scheffer, M.; Chapin, T.; Rockström, J. Resilience thinking: Integrating resilience, adaptability and transformability. Ecol. Soc. 2010, 15, 20. [CrossRef]

22. WCED. Our Common Future, 1st ed.; The World Commission on Environment and Development (WCED), Oxford University Press: Oxford, UK, 1987; p. 400.

23. OECD. Glossary of Statistical Terms-Sustainable Agriculture; The Organisation for Economic Co-operation and Development (OECD): Paris, France, 2003. Available online: https://stats.oecd.org/glossary/detail.asp?ID= 2624 (accessed on 28 February 2019).

24. Ikerd, J.E. The need for a systems approach to sustainable agriculture. Agric. Ecosyst. Environ. 1993, 46, 147-160. [CrossRef]

25. Tomich, T.P.; Brodt, S.; Ferris, H.; Galt, R.; Horwath, W.R.; Kebreab, E.; Leveau, J.H.J.; Liptzin, D.; Lubell, M.; Merel, P.; et al. Agroecology: A review from a global-change perspective. Annu. Rev. Environ. Resour. 2011, 36, 193-222. [CrossRef]

26. Roberts, D.P.; Mattoo, A.K. Sustainable agriculture-Enhancing environmental benefits, food nutritional quality and building crop resilience to abiotic and biotic stresses. Agric. Lond. 2018, 8, 8. [CrossRef]

27. Barbeau, C.; Oelbermann, M.; Karagatzides, J.; Tsuji, L. Sustainable agriculture and climate change: Producing potatoes (Solanum tuberosum L.) and bush beans (Phaseolus vulgaris L.) for improved food security and resilience in a canadian subarctic first nations community. Sustainability 2015, 7, 5664-5681. [CrossRef]

28. Ellegaard, O.; Wallin, J.A. The bibliometric analysis of scholarly production: How great is the impact? Scientometrics 2015, 105, 1809-1831. [CrossRef]

29. Popping, R. Knowledge graphs and network text analysis. Soc. Sc. Inform. 2003, 42, 91-106. [CrossRef]

30. Ferguson, R.S.; Lovell, S.T. Permaculture for agroecology: Design, movement, practice, and worldview. A review. Agron. Sustain. Dev. 2014, 34, 251-274. [CrossRef]

31. Paranyushkin, D. Identifying the Pathways for Meaning Circulation using Text. Network Analysis; Nodus Labs: Berlin, Germany, 2011. Available online: https://noduslabs.com/category/research/ (accessed on 28 February 2019).

32. Porter, M.F. An algorithm for suffix stripping. Program 1980, 14, 130-137. [CrossRef]

33. Krovetz, R. Viewing Morphology as an Inference Process. Artif. Intell. 2000, 118, 277-294. [CrossRef]

34. Bastian, M.; Heymann, S.; Jacomy, M. Gephi: An open source software for exploring and manipulating networks. In Proceedings of the Third International AAAI Conference on Weblogs and Social Media, San Jose, CA, USA, 17-20 May 2009.

35. CEE. Guidelines for Systematic Review and Evidence Synthesis in Environmental Management; Version, 5.0; Pullin, A.S., Ed.; Collaboration for Environmental Evidence (CEE): Bangor, UK, 2018. Available online: www.environmentalevidence.org/information-for-authors (accessed on 28 February 2019).

36. Pullin, A.S.; Knight, T.M.; Watkinson, A.R. Linking reductionist science and holistic policy using systematic reviews: Unpacking environmental policy questions to construct an evidence-based framework. J. Appl. Ecol. 2009, 46, 970-975. [CrossRef]

37. Tait, J.; Morris, D. Sustainable development of agricultural systems: Competing objectives and critical limits. Futures 2000, 32, 247-260. [CrossRef] 
38. Moher, D.; Liberati, A.; Tetzlaff, J.; Altman, D.G. Preferred reporting items for systematic reviews and meta-analyses: The PRISMA statement. Ann. Intern. Med. 2009, 151, 264-269. [CrossRef] [PubMed]

39. Doran, J.W. Soil health: Agent of sustainable management and environmental remediation. In Innovative Soil-Plant. Systems for Sustainable Agricultural Practices; Lynch, J.M., Schepers, J.S., Ünver, I., Eds.; Organisation for Economic Cooperation and Development (OECD): Paris, France, 2003; pp. 184-194. [CrossRef]

40. McGranahan, D.A. Ecologies of scale: Multifunctionality connects conservation and agriculture across fields, farms, and landscapes. Land 2014, 3, 739-769. [CrossRef]

41. DeLonge, M.; Basche, A. Leveraging agroecology for solutions in food, energy, and water. Elementa $2017,5,6$. [CrossRef]

42. Garibaldi, L.A.; Gemmill-Herren, B.; D'Annolfo, R.; Graeub, B.E.; Cunningham, S.A.; Breeze, T.D. Farming approaches for greater biodiversity, livelihoods, and food security. Trends Ecol. Evol. 2017, 32, 68-80. [CrossRef]

43. FAO. Climate-Smart Agriculture-Sourcebook; The UN Food and Agriculture Organisation (FAO): Rome, Italy, 2013; p. 557. Available online: http://www.fao.org/3/a-i3325e.pdf (accessed on 28 February 2019).

44. Harvey, C.A.; Martínez-Rodríguez, M.R.; Cárdenas, J.M.; Avelino, J.; Rapidel, B.; Vignola, R.; Donatti, C.I.; Vilchez-Mendoza, S. The use of Ecosystem-based Adaptation practices by smallholder farmers in Central America. Agr. Ecosyst. Environ. 2017, 246, 279-290. [CrossRef]

45. Altieri, M.A.; Koohafkan, P. Enduring Farms: Climate Change, Smallholders and Traditional Farming Communities; Environment \& Development Series 6; Third World Network (TWN): Penang, Malasya, 2008; p. 63.

46. Thierfelder, C.; Baudron, F.; Setimela, P.; Nyagumbo, I.; Mupangwa, W.; Mhlanga, B.; Lee, N.; Gérard, B. Complementary practices supporting conservation agriculture in Southern Africa. A review. Agron. Sustain. Dev. 2018, 38, 16. [CrossRef]

47. Romero-Perezgrovas, R.; Verhulst, N.; De La Rosa, D.; Hernandez, V.; Maertens, M.; Deckers, J.; Govaerts, B. Effects of tillage and crop residue management on maize yields and net returns in the central mexican highlands under drought conditions. Pedosphere 2014, 24, 476-486. [CrossRef]

48. Steward, P.R.; Dougill, A.J.; Thierfelder, C.; Pittelkow, C.M.; Stringer, L.C.; Kudzala, M.; Shackelford, G.E. The adaptive capacity of maize-based conservation agriculture systems to climate stress in tropical and subtropical environments: A meta-regression of yields. Agric. Ecosyst. Environ. 2018, 251, 194-202. [CrossRef]

49. Sommer, R.; Paul, B.K.; Mukalama, J.; Kihara, J. Reducing losses but failing to sequester carbon in soils-the case of conservation agriculture and integrated soil fertility management in the humid tropical agro-ecosystem of western kenya. Agric. Ecosyst. Environ. 2018, 254, 82-91. [CrossRef]

50. Rockström, J.; Williams, J.; Daily, G.; Noble, A.; Matthews, N.; Gordon, L.; Wetterstand, H.; DeClerck, F.; Shah, M.; Steduto, P.; et al. Sustainable intensification of agriculture for human prosperity and global sustainability. Ambio 2017, 46, 4-17. [CrossRef] [PubMed]

51. Smith, A.; Snapp, S.; Chikowo, R.; Thorne, P.; Bekunda, M.; Glover, J. Measuring sustainable intensification in smallholder agroecosystems: A review. Glob. Food Secur. 2017, 12, 127-138. [CrossRef]

52. Weltin, M.; Zasada, I.; Piorr, A.; Debolini, M.; Geniaux, G.; Moreno Perez, O.; Scherer, L.; Tudela Marco, L.; Schulp, C.J.E. Conceptualising fields of action for sustainable intensification-A systematic literature review and application to regional case studies. Agric. Ecosyst. Environ. 2018, 257, 68-80. [CrossRef]

53. Ares, A.; Thierfelder, C.; Reyes, M.; Eash, N.S.; Himmelstein, J. Global perspectives on conservation agriculture for small households. In Conservation Agriculture in Subsistence Farming: Case Studies from South. Asia and Beyond; Chan, C., Fantle-Lepczyk, J., Eds.; CAB International: Wallingford, UK, 2015; pp. $22-54$.

54. Franzluebbers, A.J.; Sulc, R.M.; Russelle, M.P. Opportunities and challenge for integrating North-American crop and livestock systems. In Grassland Productivity and Ecosystem Services; Lemaire, G., Hodgson, J., Chabbi, A., Eds.; CAB International: Wallingford, UK, 2011; pp. 208-218. [CrossRef]

55. Gil, J.D.B.; Cohn, A.S.; Duncan, J.; Newton, P.; Vermeulen, S. The Resilience of Integrated Agricultural Systems to Climate Change. Wiley Interdiscip. Rev. Clim. Chang. 2017, 8, e461. [CrossRef]

56. Hendrickson, J.R.; Hanson, J.D.; Tanaka, D.L.; Sassenrath, G. Principles of integrated agricultural systems: Introduction to processes and definition. Renew. Agric. Food. Syst. 2008, 23, 265-271. [CrossRef]

57. Atanga, N.L.; Treydte, A.C.; Birner, R. Assessing the sustainability of different small-scale livestock production systems in the Afar Region, Ethiopia. Land 2013, 2, 726-755. [CrossRef]

58. Duru, M.; Therond, O. Livestock system sustainability and resilience in intensive production zones: Which form of ecological modernization? Reg. Environ. Chang. 2015, 15, 1651-1665. [CrossRef] 
59. IFOAM. Definition of Organic Agriculture; The International Federation of Organic Agriculture Movements (IFOAM): Bonn, Germany, 2019. Available online: https://www.ifoam.bio/en/organic-landmarks/definitionorganic-agriculture (accessed on 28 February 2019).

60. Kloos, J.; Renaud, F.G. Organic cotton production as an adaptation option in North-West Benin. Outlook Agric. 2014, 43, 91-100. [CrossRef]

61. Lechenet, M.; Bretagnolle, V.; Bockstaller, C.; Boissinot, F.; Petit, M.-S.; Petit, S.; Munier-Jolain, N.M. Reconciling pesticide reduction with economic and environmental sustainability in arable farming. PLoS ONE 2014, 9, e97922. [CrossRef]

62. Ponisio, L.C.; Ehrlich, P.R. Diversification, Yield and a new agricultural revolution: Problems and prospects. Sustainability 2016, 8, 1118. [CrossRef]

63. Shennan, C.; Krupnik, T.J.; Baird, G.; Cohen, H.; Forbush, K.; Lovell, R.J.; Olimpi, E.M. Organic and conventional agriculture: A useful framing? Annu. Rev. Environ. Resour. 2017, 42, 317-346. [CrossRef]

64. Meemken, E.-M.; Qaim, M. Organic agriculture, food security, and the environment. Annu. Rev. Resour. Econ. 2018, 10, 39-63. [CrossRef]

65. Lotter, D.W.; Seidel, R.; Liebhardt, W. The performance of organic and conventional cropping systems in an extreme climate year. Am. J. Altern. Agric. 2003, 18, 146-154. [CrossRef]

66. Denison, R.F.; Bryant, D.C.; Kearney, T.E. Crop yields over the first nine years of ltras, a long-term comparison of field crop systems in a mediterranean climate. Field Crop. Res. 2004, 86, 267-277. [CrossRef]

67. IFOAM. The Contribution of Organic Agriculture to Climate Change Mitigation; The International Federation of Organic Agriculture Movements (IFOAM): Bonn, Germany, 2009; p. 71. Available online: http://www.ifoameu.org/sites/default/files/ifoameu_advocacy_climate_change_report_2016.pdf (accessed on 28 February 2019).

68. Jacobi, J.; Schneider, M.; Pillco Mariscal, M.; Huber, S.; Weidmann, S.; Bottazzi, P.; Rist, S. Farm resilience in organic and nonorganic cocoa farming systems in Alto Beni, Bolivia. Agroecol. Sustain. Food Syst. 2015, 39, 798-823. [CrossRef]

69. Seufert, V.; Ramankutty, N. Many shades of gray-the context-dependent performance of organic agriculture. Sci. Adv. 2017, 3, e1602638. [CrossRef]

70. Binta, B.A.A.; Barbier, B. Economic and environmental performances of organic farming system compared to conventional farming system: A case study of the horticulture sector in the niayes region of senegal. Procedia Environ. Sci. 2015, 29, 17-19. [CrossRef]

71. FAO. Food Security and Agricultural Mitigation in Developing Countries: Options for Capturing Synergies; Food and Agriculture Organization of the United Nations (FAO): Rome, Italy, 2009; p. 80. Available online: http://www.fao.org/docrep/012/i1318e/i1318e00.pdf (accessed on 28 February 2019).

72. Lipper, L.; Zilberman, D. A short history of the evolution of the climate smart agriculture approach and its links to climate change and sustainable agriculture debates. In Climate Smart Agriculture: Building Resilience to Climate Change; Lipper, L., McCarthy, N., Zilberman, D., Asfaw, S., Branca, G., Eds.; Natural Resource Management and Policy, 52; Springer Nature: Basel, Switzerland, 2018; pp. 13-30. [CrossRef]

73. FAO. Climate-Smart Agriculture-Sourcebook Summary; The UN Food and Agriculture Organisation (FAO): Rome, Italy, 2017; p. 47. Available online: http://www.fao.org/3/a-i7994e.pdf (accessed on 28 February 2019).

74. Lipper, L.; McCarthy, N.; Zilberman, D.; Asfaw, S.; Branca, G. Climate Smart Agriculture: Building Resilience to Climate Change; Natural Resource Management and Policy, 52; Springer Nature: Basel, Switzerland, 2018; p. 630. [CrossRef]

75. Rosenstock, T.S.; Lamanna, C.; Chesterman, S.; Bell, P.; Arslan, A.; Richards, M.; Rioux, J.; Akinleye, A.O.; Champalle, C.; Cheng, Z.; et al. The Scientific Basis of Climate-Smart Agriculture: A systematic Review Protocol; CCAFS Working Paper no. 138; CGIAR Research Program on Climate Change, Agriculture and Food Security (CCAFS): Copenhagen, Denmark, 2016.

76. Were, K.; Gelaw, A.M.; Singh, B.R. Smart strategies for enhanced agricultural resilience and food security under a changing climate in sub-saharan Africa. In Climate Change and Multi-Dimensional Sustainability in African Agriculture: Climate Change and Sustainability in Agriculture; Lal, R., Kraybill, D., Hansen, D.O., Singh, B.R., Mosogoya, T., Eik, L.O., Eds.; Springer Nature: Basel, Switzerland, 2016; pp. 431-453. [CrossRef]

77. Imran, M.A.; Ali, A.; Ashfaq, M.; Hassan, S.; Culas, R.; Ma, C. Impact of Climate Smart Agriculture (CSA) practices on cotton production and livelihood of farmers in Punjab, Pakistan. Sustainability 2018, 10, 2101. [CrossRef] 
78. Ryan, J.; Kapur, S.; Ibrikci, H.; Singh, M. Cultivation intensity in relation to organic matter and related properties in a vertisol in Southern Turkey. J. Sustain. Agric. 2011, 35, 613-623. [CrossRef]

79. Zhang, B.; Wang, H.; Yao, S.; Bi, L. Litter quantity confers soil functional resilience through mediating soil biophysical habitat and microbial community structure on an eroded bare land restored with mono pinus massoniana. Soil Biol. Biochem. 2013, 57, 556-567. [CrossRef]

80. Mahanta, D.; Bhattacharyya, R.; Gopinath, K.A.; Tuti, M.D.; Jeevanandan, K.; Chandrashekara, C.; Arunkumar, R.; Mina, B.L.; Pandey, B.M.; Mishra, P.K.; et al. Influence of farmyard manure application and mineral fertilization on yield sustainability, carbon sequestration potential and soil property of gardenpea-french bean cropping system in the indian himalayas. Sci. Hortic. 2013, 164, 414-427. [CrossRef]

81. Abrol, V.; Ben-Hur, M.; Verheijen, F.G.A.; Keizer, J.J.; Martins, M.A.S.; Tenaw, H.; Tchehansky, L.; Graber, E.R. Biochar effects on soil water infiltration and erosion under seal formation conditions: Rainfall simulation experiment. J. Soils Sediments 2016, 16, 2709-2719. [CrossRef]

82. Kamran, M.A.; Jiang, J.; Li, J.-Y.; Shi, R.-Y.; Mehmood, K.; Baquy, M.A.-A.; Xu, R.-K. Amelioration of soil acidity, olsen-p, and phosphatase activity by manure- and peat-derived biochars in different acidic soils. Arab. J. Geosci. 2018, 11. [CrossRef]

83. Lee, C.-H.; Wang, C.-C.; Lin, H.-H.; Lee, S.S.; Tsang, D.C.W.; Jien, S.-H.; Ok, Y.S. In-situ biochar application conserves nutrients while simultaneously mitigating runoff and erosion of an fe-oxide-enriched tropical soil. Sci. Total Environ. 2018, 619-620, 665-671. [CrossRef] [PubMed]

84. Sun, F.; Pan, K.; Li, Z.; Wang, S.; Tariq, A.; Olatunji, O.A.; Sun, X.; Zhang, L.; Shi, W.; Wu, X. Soybean supplementation increases the resilience of microbial and nematode communities in soil to extreme rainfall in an agroforestry system. Sci. Total Environ. 2018, 626, 776-784. [CrossRef]

85. Yu, J.; Deem, L.M.; Crow, S.E.; Deenik, J.L.; Penton, C.R. Biochar application influences microbial assemblage complexity and composition due to soil and bioenergy crop type interactions. Soil Biol. Biochem. 2018, 117, 97-107. [CrossRef]

86. Luo, G.; Li, L.; Friman, V.-P.; Guo, J.; Guo, S.; Shen, Q.; Ling, N. Organic amendments increase crop yields by improving microbe-mediated soil functioning of agroecosystems: A meta-analysis. Soil Biol. Biochem. 2018, 124, 105-115. [CrossRef]

87. Acharya, C.L.; Bandyopadhyay, K.K. Mulches: Role in Climate Resilient Agriculture. In Encyclopedia of Soils in the Environment; Hillel, D., Rosenzweig, C., Powlson, D.S., Scow, K.M., Singer, M.J., Sparks, D.L., Hatfield, J., Eds.; Earth Systems and Environmental Sciences; Elsevier: Amsterdam, The Netherlands, 2018; pp. 521-532. [CrossRef]

88. Alliaume, F.; Rossing, W.A.H.; Tittonell, P.; Jorge, G.; Dogliotti, S. Reduced tillage and cover crops improve water capture and reduce erosion of fine textured soils in raised bed tomato systems. Agric. Ecosyst. Environ. 2014, 183, 127-137. [CrossRef]

89. Kahlon, M.S.; Lal, R. Enhancing green water in soils of South Asia. J. Crop. Improv. 2011, 25, 101-133. [CrossRef]

90. Jiang, H.; Han, X.; Zou, W.; Hao, X.; Zhang, B. Seasonal and long-term changes in soil physical properties and organic carbon fractions as affected by manure application rates in the mollisol region of Northeast China. Agric. Ecosyst. Environ. 2018, 268, 133-143. [CrossRef]

91. Villagra-Mendoza, K.; Horn, R. Effect of biochar addition on hydraulic functions of two textural soils. Geoderma 2018, 326, 88-95. [CrossRef]

92. Arnés, E.; Antonio, J.; Del Val, E.; Astier, M. Sustainability and climate variability in low-input peasant maize systems in the Central Mexican Highlands. Agric. Ecosyst. Environ. 2013, 181, 195-205. [CrossRef]

93. Bista, P.; Norton, U.; Ghimire, R.; Norton, J.B. Effects of tillage system on greenhouse gas fluxes and soil mineral nitrogen in wheat (triticum aestivum, 1.)-fallow during drought. J. Arid Environ. 2017, 147, 103-113. [CrossRef]

94. Maaz, T.M.; Schillinger, W.F.; Machado, S.; Brooks, E.; Johnson-Maynard, J.L.; Young, L.E.; Young, F.L.; Leslie, I.; Glover, A.; Madsen, I.J.; et al. Impact of climate change adaptation strategies on winter wheat and cropping system performance across precipitation gradients in the inland pacific northwest, USA. Front. Environ. Sci. 2017, 5, 23. [CrossRef]

95. Mupangwa, W.; Mutenje, M.; Thierfelder, C.; Nyagumbo, I. Are conservation agriculture (ca) systems productive and profitable options for smallholder farmers in different agro-ecoregions of zimbabwe? Renew. Agric. Food Syst. 2017, 32, 87-103. [CrossRef] 
96. Chen, Y.; Camps-Arbestain, M.; Shen, Q.; Singh, B.; Cayuela, M.L. The long-term role of organic amendments in building soil nutrient fertility: A meta-analysis and review. Nutr. Cycl. Agroecosyst. 2018, 111, 103-125. [CrossRef]

97. Powlson, D.S.; Stirling, C.M.; Jat, M.L.; Gerard, B.G.; Palm, C.A.; Sanchez, P.A.; Cassman, K.G. Limited potential of no-till agriculture for climate change mitigation. Nat. Clim. Chang. 2014, 4, 678-683. [CrossRef]

98. Zhang, H.-L.; Lal, R.; Zhao, X.; Xue, J.-F.; Chen, F. Opportunities and challenges of soil carbon sequestration by conservation agriculture in China. Adv. Agron. 2014, 124, 1-36. [CrossRef]

99. Doswald, N.; Osti, M. Ecosystem-Based Approaches to Adaptation and Mitigation-Good Practice Examples and Lessons Learned in Europe; German Federal Agency for Nature Conservation (BfN): Bonn, Germany, 2011; p. 43.

100. FAO. Save and Grow in Practice: Maize, Rice, Wheat. A Guide to Sustainable Cereal Production; The UN Food and Agriculture Organisation (FAO): Rome, Italy, 2016; p. 109. Available online: http://www.fao.org/3/a-i4009e.pdf (accessed on 28 February 2019).

101. Vignola, R.; Harvey, C.A.; Bautista-Solis, P.; Avelino, J.; Rapidel, B.; Donatti, C.; Martinez, R. Ecosystem-based adaptation for smallholder farmers: Definitions, opportunities and constraints. Agr. Ecosyst. Environ. 2015, 211, 126-132. [CrossRef]

102. Gagné-Bourque, F.; Bertrand, A.; Claessens, A.; Aliferis, K.A.; Jabaji, S. Alleviation of drought stress and metabolic changes in timothy (Phleum Pratense L.) colonized with bacillus subtilis B26. Front. Plant. Sci. 2016, 7, 584. [CrossRef]

103. Kaye, J.P.; Quemada, M. Using cover crops to mitigate and adapt to climate change. A review. Agron. Sustain. Dev. 2017, 37, 4. [CrossRef]

104. Khan, N.; Bano, A.; Shahid, M.A.; Nasim, W.; Ali Babar, M. Interaction between PGPR and PGR for Water Conservation and Plant Growth Attributes under Drought Condition. Biologia 2018, 73, 1083-1098. [CrossRef]

105. Kritee, K.; Nair, D.; Tiwari, R.; Rudek, J.; Ahuja, R.; Adhya, T.; Loecke, T.; Hamburg, S.; Tetaert, F.; Reddy, S.; et al. Groundnut cultivation in semi-arid peninsular india for yield scaled nitrous oxide emission reduction. Nutr. Cycl. Agroecosyst. 2015, 103, 115-129. [CrossRef]

106. Ratnakumar, P.; Khan, M.I.R.; Minhas, P.S.; Farooq, M.A.; Sultana, R.; Per, T.S.; Deokate, P.P.; Khan, N.A.; Singh, Y.; Rane, J. Can plant bio-regulators minimize crop productivity losses caused by drought, salinity and heat stress? An integrated review. J. Appl. Bot. Food Qual. 2016, 89, 113-125. [CrossRef]

107. Delaquis, E.; de Haan, S.; Wyckhuys, K.A.G. On-farm diversity offsets environmental pressures in tropical agro-ecosystems: A synthetic review for cassava-based systems. Agric. Ecosyst. Environ. 2018, 251, $226-235$. [CrossRef]

108. Gouda, S.; Nayak, S.; Bishwakarma, S.; Kerry, R.G.; Das, G.; Patra, J.K. Role of microbial technology in agricultural sustainability. Microb. Biotechnol. 2018, 1, 181-202. [CrossRef]

109. FAO. Landscapes for Life-Approaches to Landscape Management for Sustainable Food and Agriculture; Food and Agriculture Organization of the United Nations (FAO): Rome, Italy, 2017; p. 47. Available online: http://www.fao.org/3/i8324en/i8324en.pdf (accessed on 28 February 2019).

110. Handa, A.K.; Chavan, S.B.; Sirohi, C.; Rizvi, R.H. Importance of agroforestry systems in carbon sequestration. In Proceedings of the National Agroforestry Symposium 2020 (NAFS 2020) on Climate Resilient Agroforestry Systems to Augment Livestock Productivity Ensuring Environmental Biodiversity, New Delhi, India, 5-6 March 2020; pp. 221-235.

111. Kosmowski, F. Soil water management practices (terraces) helped to mitigate the 2015 drought in Ethiopia. Agr. Water. Manag. 2018, 204, 11-16. [CrossRef]

112. Fleming, W.M.; Rivera, J.A.; Miller, A.; Piccarello, M. Ecosystem services of traditional irrigation systems in Northern New Mexico, USA. Int. J. Biodivers. Sci. Ecosyst. Serv. Manag. 2014, 10, 343-350. [CrossRef]

113. Wei, W.; Chen, D.; Wang, L.; Daryanto, S.; Chen, L.; Yu, Y.; Lu, Y.; Sun, G.; Feng, T. Global synthesis of the classifications, distributions, benefits and issues of terracing. Earth Sci. Rev. 2016, 159, 388-403. [CrossRef]

114. Dile, Y.T.; Karlberg, L.; Temesgen, M.; Rockström, J. The role of water harvesting to achieve sustainable agricultural intensification and resilience against water related shocks in Sub-Saharan Africa. Agric. Ecosyst. Environ. 2013, 181, 69-79. [CrossRef]

115. Vohland, K.; Barry, B. A Review of in situ rainwater harvesting (rwh) practices modifying landscape functions in African Drylands. Agric. Ecosyst. Environ. 2009, 131, 119-127. [CrossRef] 
116. Martin-Gorriz, B.; Soto-García, M.; Martínez-Alvarez, V. Energy and greenhouse-gas emissions in irrigated agriculture of se (southeast) spain. effects of alternative water supply scenarios. Energy 2014, 77, 478-488. [CrossRef]

117. Key, S.; Ma, J.K.-C.; Drake, P.M. Genetically modified plants and human health. J. Roy. Soc. Med. 2008, 101, 290-298. [CrossRef] [PubMed]

118. Tsatsakis, A.M.; Nawaz, M.A.; Kouretas, D.; Balias, G.; Savolainen, K.; Tutelyan, V.A.; Golokhvast, K.S.; Lee, J.D.; Yang, S.H.; Chung, G. Environmental impacts of genetically modified plants: A review. Environ. Res. 2017, 156, 818-833. [CrossRef]

119. Lammerts van Bueren, E.T.; Struik, P.C.; van Eekeren, N.; Nuijten, E. Towards resilience through systems-based plant breeding. A review. Agron. Sustain. Dev. 2018, 38, 42. [CrossRef]

120. Di Falco, S.; Chavas, J.-P. Rainfall shocks, resilience, and the effects of crop biodiversity on agroecosystem productivity. Land Econ. 2008, 84, 83-96. [CrossRef]

121. Félix, G.F.; Diedhiou, I.; Le Garff, M.; Timmermann, C.; Clermont-Dauphin, C.; Cournac, L.; Groot, J.C.J.; Tittonell, P. Use and management of biodiversity by smallholder farmers in Semi-Arid West Africa. Glob. Food Sec. 2018, 18, 76-85. [CrossRef]

122. Pollnac, F.W.; Smith, R.G.; Warren, N.D. Cultivar diversity as a means of ecologically intensifying dry matter production in a perennial forage stand. Ecosphere 2014, 5, 115. [CrossRef]

123. Matsushita, K.; Yamane, F.; Asano, K. Linkage between crop diversity and agro-ecosystem resilience: Nonmonotonic agricultural response under alternate regimes. Ecol. Econ. 2016, 126, 23-31. [CrossRef]

124. Sanderson, M.A.; Archer, D.; Hendrickson, J.; Kronberg, S.; Liebig, M.; Nichols, K.; Schmer, M.; Tanaka, D.; Aguilar, J. Diversification and ecosystem services for conservation agriculture: Outcomes from pastures and integrated crop-livestock systems. Renew. Agric. Food Syst. 2013, 28, 129-144. [CrossRef]

125. Calderón, C.I.; Jerónimo, C.; Praun, A.; Reyna, J.; Santos Castillo, I.D.; León, R.; Hogan, R.; Prado Córdova, J.P. Agroecology-based farming provides grounds for more resilient livelihoods among smallholders in Western Guatemala. Agroecol. Sustain. Food Syst. 2018, 42, 1128-1169. [CrossRef]

126. Newman, B.D.; Conrad, K.W. A framework for characterizing knowledge management methods, practices, and technologies. In CEUR Workshop Proceedings; Reimer, U., Ed.; Swiss Life: Zurich, Switzerland, 2000. Available online: http://sunsite.informatik.rwth-aachen.de/Publications/CEUR-WS/Vol-34/ (accessed on 28 February 2019).

127. Boom, D. The Asian Development Bank's knowledge management framework. Knowl. Manag. Dev. J. 2005, 1, 69-75. Available online: www.km4dev.org/journal (accessed on 28 February 2019).

128. Hibbard, J. Knowing what we know. Inf. Week 1997, 653, 46-54.

129. Nacipucha, D.; Ruhanen, L.; Cooper, C. Adaption to climate change: A knowledge management approach. Anatolia 2017, 28, 422-431. [CrossRef]

130. Šūmane, S.; Kunda, I.; Knickel, K.; Strauss, A.; Tisenkopts, T.; des los Rios, I.; Rivera, M.; Chebach, T.; Ashkenazy, A. Local and farmers' knowledge matters! How integrating informal and formal knowledge enhances sustainable and resilient agriculture. J. Rural Stud. 2018, 59, 232-241. [CrossRef]

131. Tenywa, M.M.; Zake, J.Y.K.; Lal, R. Building upon traditional knowledge to enhance resilience of soils in sub-saharan Africa. In Principles of Sustainable Soil Management in Agroecosystems; Lal, R., Stewart, B.A., Eds.; Taylor \& Francis Group: Abingdon, UK, 2013; pp. 109-140. [CrossRef]

132. Hirsch Hadorn, G.; Bradley, D.; Pohl, C.; Rist, S.; Wiesmann, U. Implications of transdisciplinarity for sustainability research. Ecol. Econ. 2006, 60, 119-128. [CrossRef]

133. Brandt, P.; Ernst, A.; Gralla, F.; Luederitz, C.; Lang, D.J.; Newig, J.; Reinert, F.; Abson, D.J.; von Wehrden, H. A review of transdisciplinary research in sustainability science. Ecol. Econ. 2013, 92, 1-15. [CrossRef]

134. El Chami, D.; Daccache, A. Assessing sustainability of winter wheat production under climate change scenarios in a humid climate-An integrated modelling framework. Agric. Syst. 2015, 140, 19-25. [CrossRef]

135. Gaillard, G.; Nemecek, T. 6th international conference on LCA in the agri-food sector. Int. J. Life Cycle Assess. 2009, 14, 687-689. [CrossRef]

136. Lüscher, G.; Nemecek, T.; Arndorfer, M.; Balázs, K.; Dennis, P.; Fjellstad, W.; Friedel, J.K.; Gaillard, G.; Herzog, F.; Sarthou, J.-P.; et al. Biodiversity assessment in LCA: A validation at field and farm scale in eight European regions. Int. J. Life Cycle Assess. 2017, 22, 1483-1492. [CrossRef]

137. Teillard, F.; de Souza, D.M.; Thoma, G.; Gerber, P.; Finn, J. What does Life-Cycle Assessment of agricultural products need for more meaningful inclusion of biodiversity? J. Appl. Ecol. 2016, 53, 1422-1429. [CrossRef] 
138. Scialabba, N.E.-H.; Müller-Lindenlauf, M. Organic agriculture and climate change. Renew. Agric. Food Syst. 2010, 25, 158-169. [CrossRef]

139. Curran, M.A. Life cycle assessment. Enc. Ecol. 2008, 2168-2174. [CrossRef]

(C) 2020 by the authors. Licensee MDPI, Basel, Switzerland. This article is an open access article distributed under the terms and conditions of the Creative Commons Attribution (CC BY) license (http://creativecommons.org/licenses/by/4.0/). 